\title{
Applications of CRISPR-Cas9 as an Advanced Genome Editing System in Life Sciences
}

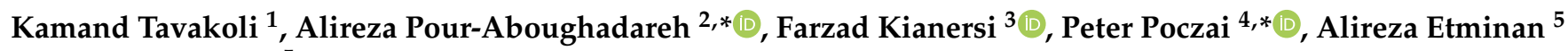 \\ and Lia Shooshtari ${ }^{5}$
}

1 Department of Medical Laboratory Science, Kermanshah Branch, Islamic Azad University, Kermanshah P.O. Box 6718997551, Iran; kamandtavakoli@yahoo.com

2 Seed and Plant Improvement Institute, Agricultural Research, Education and Extension Organization (AREEO), Karaj P.O. Box 3158854119, Iran

3 Department of Agronomy and Plant Breeding, Faculty of Agriculture, Bu-Ali Sina University, Hamedan P.O. Box 6517838695, Iran; f.kianersi@agr.basu.ac.ir

4 Botany Unit, Finnish Museum of Natural History, University of Helsinki, P.O. Box 7, FI-00014 Helsinki, Finland

5 Department of Plant Breeding and Biotechnology, Kermanshah Branch, Islamic Azad University, Kermanshah P.O. Box 6718997551, Iran; alietminan55@yahoo.com (A.E.); L_shooshtary@yahoo.com (L.S.)

* Correspondence: a.poraboghadareh@edu.ikiu.ac.ir (A.P.-A.); peter.poczai@helsinki.fi (P.P.)

Citation: Tavakoli, K

Pour-Aboughadareh, A.; Kianersi, F.; Poczai, P.; Etminan, A.; Shooshtari, L. Applications of CRISPR-Cas9 as an Advanced Genome Editing System in Life Sciences. BioTech 2021, 10, 14 https://doi.org/10.3390/

biotech10030014

Academic Editor: Alfonso Urbanucci

Received: 24 March 2021

Accepted: 25 June 2021

Published: 6 July 2021

Publisher's Note: MDPI stays neutral with regard to jurisdictional claims in published maps and institutional affiliations.

Copyright: (c) 2021 by the authors. Licensee MDPI, Basel, Switzerland. This article is an open access article distributed under the terms and conditions of the Creative Commons Attribution (CC BY) license (https:/ / creativecommons.org/licenses/by/ $4.0 /)$.

\begin{abstract}
Targeted nucleases are powerful genomic tools to precisely change the target genome of living cells, controlling functional genes with high exactness. The clustered regularly interspaced short palindromic repeats associated protein 9 (CRISPR-Cas9) genome editing system has been identified as one of the most useful biological tools in genetic engineering that is taken from adaptive immune strategies for bacteria. In recent years, this system has made significant progress and it has been widely used in genome editing to create gene knock-ins, knock-outs, and point mutations. This paper summarizes the application of this system in various biological sciences, including medicine, plant science, and animal breeding.
\end{abstract}

Keywords: CRISPR system; Cas proteins; agriculture; animal science; human disease

\section{Introduction}

Significant advancements have been made in biotechnology in recent years, and the branch of genetic engineering is advancing at an unprecedented pace, yielding numerous advantages. Genome editing technology has revolutionized genetic and biological re-search via the novel ability to precisely manipulate and modify the genomes of living organisms, and by accelerating the study of functional genomics. In recent years, different genome editing tools have been utilized to study simple and intricate genomes [1,2]. Genome editing technology emerged in the 1990s, and various methods have since been developed for targeted gene editing [3,4]. In general, three systems-each with their own advantageshave been widely used in cells and animals, including transcription activator-like effector nuclease (TALEN), zinc finger nuclease (ZFN), and clustered regularly interspaced short palindromic repeats (CRISPR) [3,5]. ZFNs are targetable DNA cleavage proteins with the ability to cut DNA sequences at any location [4]. TALENs comprise double-stranded breaks (DBs) in target sequences that trigger DNA damage response pathways that lead to repair [4]. Despite the widespread application of these tools during 2002-2012, some restrictions prevent their effectual use [4]. TALENs face problems with cloning large modules in series, reduced efficiency for screening positive targeted cells, and efficient ordered affiliate by ligase [3], whilst complexity and lack of specificity are big challenges for ZFNs [2-4]. A powerful genome editing system called CRISPR emerged in 1987, which became known as the greatest genetic tool of the century due to its outstanding advantages [6]. CRISPR-Cas9 technologies took the lead over other previous methods, 
such as TALENs and ZFNs, owing to its numerous advantages, like low cost, simplicity, high efficiency, and speed. Table 1 compares their differences [7]. In this work, a short summary of the CRISPR system and its application has been reviewed.

Table 1. Main differences between three genome editing techniques.

\begin{tabular}{|c|c|c|c|}
\hline Feature & CRISPR-Cas & TALEN & ZFN \\
\hline Cost & Low & High & Low \\
\hline Ease of design & Simple & A little complex & Moderate \\
\hline Specificity & High & Intermediate & Low \\
\hline Pros & Modifies multiple sites in tandem & Highly effective and specific & Highly effective and specific \\
\hline Cons & PAM motif required next to target sequence & Time consuming & Time consuming \\
\hline Multiplex genome editing & High-yield multiplexing & Few models & Few models \\
\hline
\end{tabular}

\section{Origin, Development, and Mechanism of the CRISPR-Cas9 System}

The CRISPR was first reported by Yushizumi Ishino [8], but its biological application was unknown at the time [3]. According to effector proteins, this system has been categorized into two main classes with six subtypes [2,9]. The type2 CRISPR-Cas9 system is the most widely used item in the field of genome editing with three main components: a CRISPR RNA (cRNA), an endonuclease named Cas9, and a transactivating crRNA (tracrRNA) [6]. This system consists of two components: (1) the Cas9 protein which can cleave the DNA and (2) the guide RNA that distinguishes the sequence of DNA to be rectified. To apply CRISPR-Cas9, sequences of the intended target genome are first identified. Then, the guide RNA is tailored to recognize a particular stretch of As, Ts, Gs, and Cs in the DNA. The guide RNA is affiliated to the DNA cutting enzyme Cas9, and then this complex is presented to the target cells. Cas9 locates the target letter and cuts the DNA at that point, allowing alteration of the existing genome by either modifying or adding to the sequence (Figure 1). As such, CRISPR-Cas9 functions as a cut and paste tool for DNA editing $[10,11]$. Using this technology, any genomic sequence identified by a short strand of guide RNA can be exactly modified [12]. This system targeted the human genome for the first time in 2013 [13-15]. To date, CRISPR-Cas9 has been commonly used to create gene editing in plants, animal, and human samples. This technique is widely used in various scientific fields, including medical science and therapeutics, as well as plant and animal sciences [16-19]. 


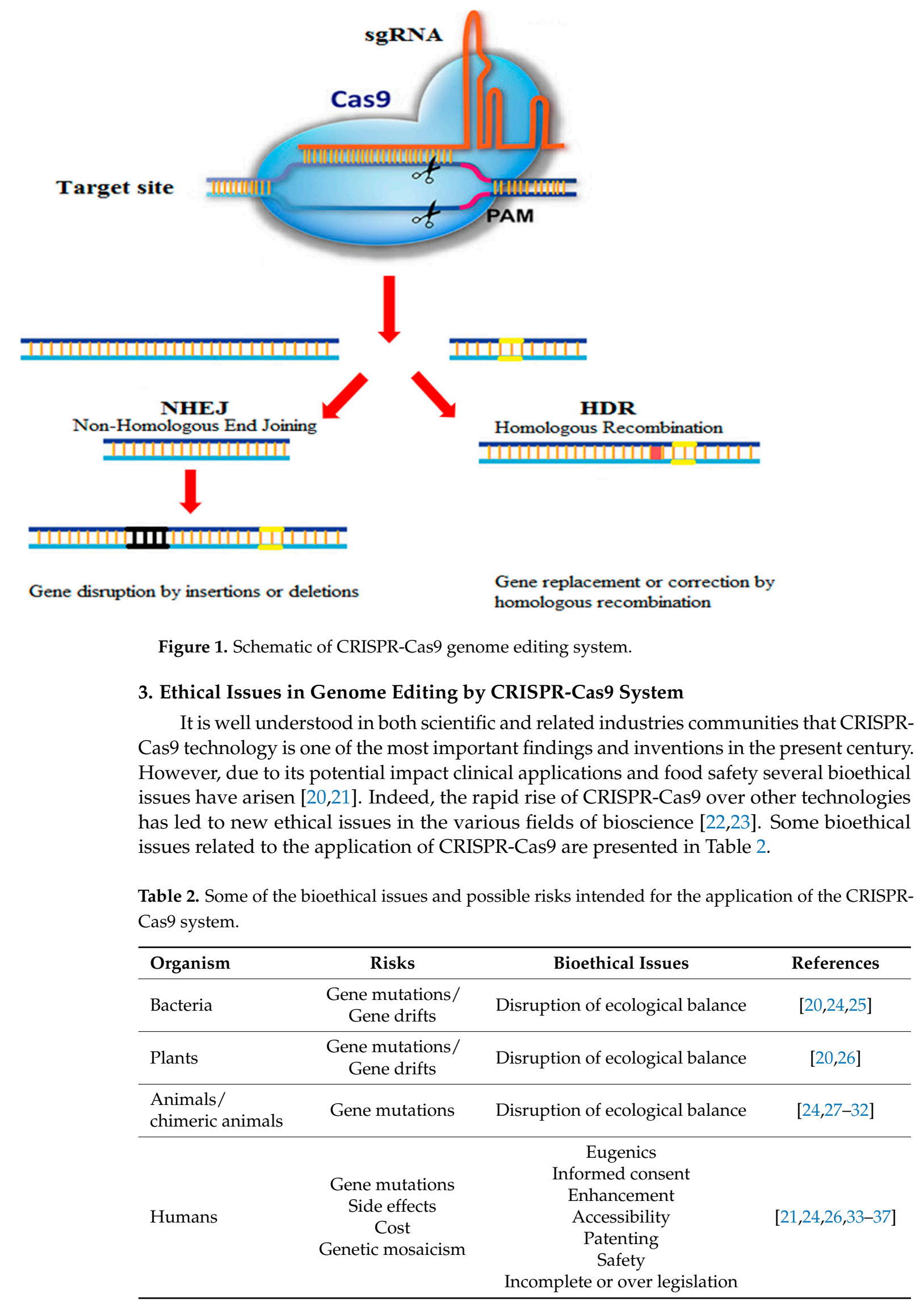




\section{Applications of CRISPER-Cas9 Technology \\ 4.1. Human Science}

Recently, CRISPR-Cas9 is being employed to study various genetic diseases, such as hemophilia [38], Duchenne muscular dystrophy [39-43], $\alpha 1$-antitrypsin deficiency [44,45], hearing loss [46,47], and hematopoietic [48-50] diseases. Figure 2 shows the application of this system in medical science. Hematologic diseases have previously been difficult to treat via genome manipulation. Studies in recent years demonstrated that CRISPRCas9 can correct genetic errors in hematopoietic stem cells that give rise to hematologic diseases [51-55]. These can then be applied to CRISPR-Cas9-based hematopoietic stem and progenitor cells (HSPCs) transplantation therapy. One of the most promising methods to treat hematopoietic diseases is editing the HBB mutation with CRISPR-Cas9, and it has been successfully carried out in patient-derived induced pluripotent stem cells (iPSCs) [56,57]. In a survey conducted by Park et al. [51], the CRISPR-Cas9 technology was used to rectify the HBB gene mutation in HSPCs. Final outcomes inferred a decrease in the amount of hemoglobin and sickle cells [17].
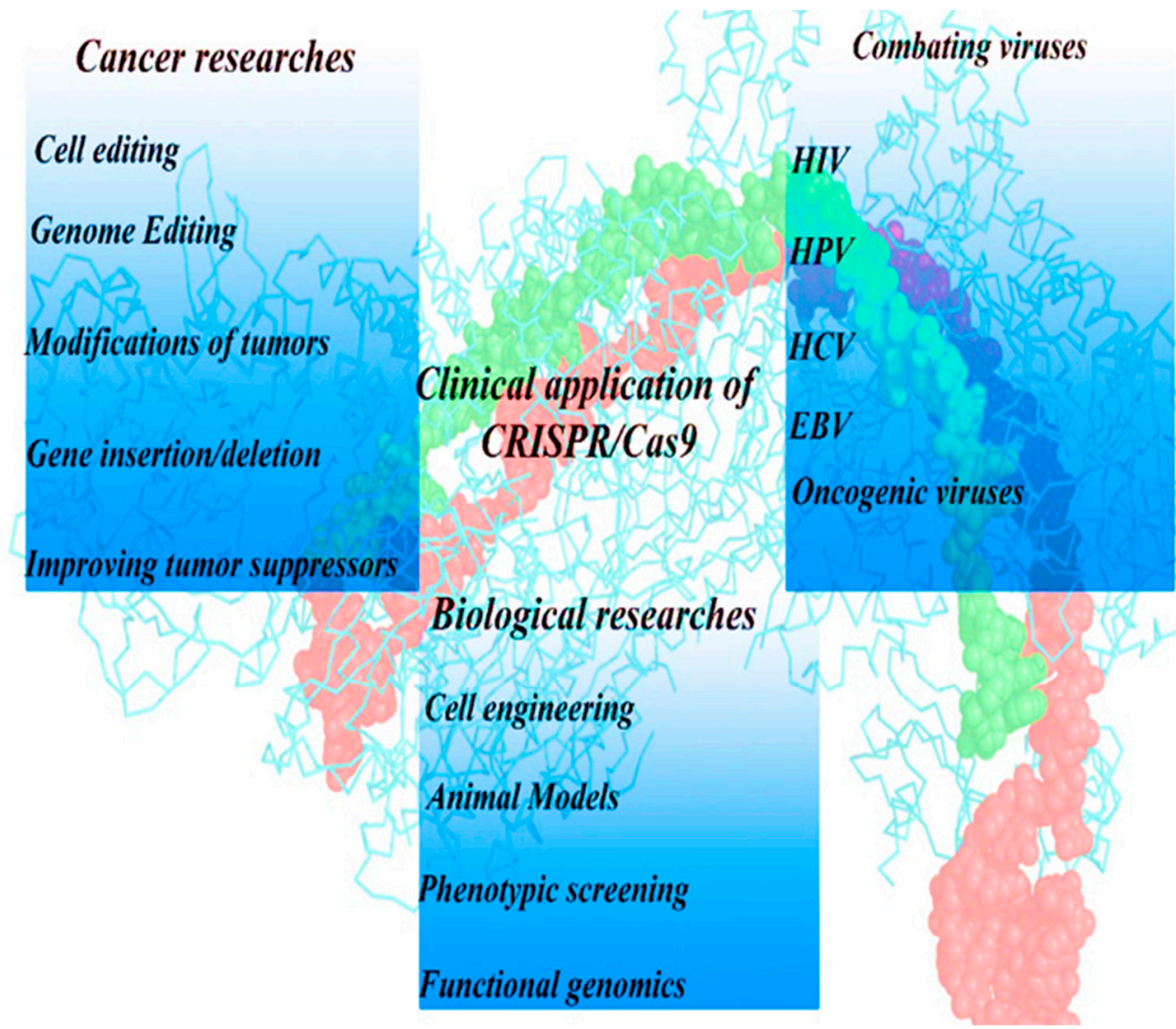

Figure 2. Exploitation of the CRISPR-Cas9 system in the field of medicine, including infectious diseases, tumors, and genetic diseases.

Since the CRISPR-Cas9 system originated from bacteria and acts as a bacterial immune system against invasive genetic agents, it has an inherent benefit in the treatment of bacterial and viral infection, and it is known as a new type of antiviral therapy against various incurable viral infections. Oncogenic viruses are highly related to carcinogenesis, including: Human papillomavirus (HPV), which could cause cervical cancer; Epstein Barr virus (EBV) that causes nasopharyngeal carcinoma; and hepatitis $B$ virus that triggers liver cancer. CRISPR-Cas9 was first used to cleave HBV genomes [58]. It has previously reported that the production of the HBV core can decrease through the HBV expression vector [17]. Among human genetic diseases, cancer is the most common cause of death 
universally [6,17]. The tumor-suppressor genes have an important role in tumorigenesis. They can downregulate cancer progression by controlling cell proliferation and differentiation. CRISPR-Cas9 technology can target tumor-suppressor genes and restore them to interdict the tumorigenesis [59]. Table 3 indicates the extensive application of the CRISPRCas9 technique to knockout proto-oncogenes supporting the potential of this method in various tumors.

Table 3. The use of CRISPR-Cas9 system in the treatment of different types of cancer [59].

\begin{tabular}{llll}
\hline Type & Oncogene & Tumor Suppressor Gene & Drug-Resistance Gene \\
\hline \multirow{2}{*}{ Breast } & SHCBP1, MIEN1, miR-27b, mi23b, & CPEB2, ETS1, BRCA1 & HER2, EGFR, ER \\
& HER2 exons & & BLS-211, NANOGP8, \\
Prostate & PCAR19, CECAM21, SENP1, & PGC1a, DEPTOR, p53, RB1 & NANOG1 \\
Lung & miR-302/367, miR-1205 & MFN2, MiR-1205, GOT1, TP53 & NRF2, MiR-1205, ER300, RSF1 \\
Liver & IGFIR, ERBB2, RSF1, FOS, MCM4 & NF1, MED12, ERK2 \\
Colorectal & Plxnb1, NCAPG, CDK7, IncBRM, Nf1 & BAP1, HELLS, Tp53, Traf3 & miR-139-5P, ZEB1 \\
CRISPR-Cas9 function & KRAS, HPV16, Fut4, NRAS & LIMCH, PTEN, SOX15 & Promote drug sensitivity \\
\hline
\end{tabular}

\subsubsection{Clinical Trials Using CRISPR-Cas9 Technology}

The United States clinical trial database [60] contains useful information on experiments that have been used various genome editing tools such as ZFN, zinc finger, and CRISPR, Cas9, Cas12, and Cas13. Clinical trials using CRISPR-based therapies are still in their primary stages. It other words, if the treatments are safe and effective, they are likely to be several years away from legal authorities. New possibilities in precision medicine have arisen with the advent of CRISPR technology. Recently, many experiments are underway for several diseases such as several types of cancer, blood disorders, chronic infections, eye diseases, and protein folding disorders. All CRISPR-related trials have been performed to edit specific cells or tissues without affecting eggs or sperm; hence no DNA changes can be transferred on to future generations during these experiments [61,62]. The first application of CRISPR-based therapy refers to February 2019 in Germany. In this ex vivo trial, twelve patients were treated, and seven of them have been followed for at least three months. As a considerable result, they have observed that the patients had not needed blood transfusions even after treatment. Recently, Hirakawa et al. [62], Frangoul et al. [63], and $\mathrm{Lu}$ et al. [64] have provided a comprehensive information on application of CRISPR in the clinical trials. Herein, we summarized some clinical trials in a complete Table (Table 4). 
Table 4. Several examples for clinical trials with genome editor of CRISPR-Cas9.

\begin{tabular}{|c|c|c|}
\hline Target Gene and Effect & Disease & Intervention \\
\hline Cas9-mediated creation of CD19 and CD20 & Leukemia & CAR T cells to CD19 and CD20 or CD19 and CD22 \\
\hline CCR5 knockout & HIV & Modified CD34+ hematopoietic stem cells \\
\hline Correction of the hemoglobulin subunit $\beta$ globulin gene & $\beta$-thalassemia & Ex vivo modified hematopoietic stem cells \\
\hline Creation of a CD19-directed T cell & Refractory B-cell malignancies & CD19-directed T-cell immunotherapy \\
\hline disruption of HPK1 & Refractory B cell malignancies & $\begin{array}{l}\text { CD19-CAR modified T cells with CAR delivered by lentivirus and } \\
\text { Cas9 knockout of HPK1 }\end{array}$ \\
\hline \multirow[t]{3}{*}{ Disruption of the erythroid enhancer to BCL11A gene } & $\beta$-thalassemia & Ex vivo modified hematopoietic stem cells \\
\hline & Sickle cell anemia & \\
\hline & $\beta$-thalassemia and severe sickle cell anemia & Ex vivo- modified hematopoietic stem cells, 15 -year follow-up study \\
\hline E6 and E7 oncogene of HPV16 and HPV18 deletion & HPV-related malignancy & Plasmid in a gel containing a polymer to facilitate delivery \\
\hline Programmed cell death protein 1 (PD-1) knockout & Hormone refractory prostate cancer & Modified T cells \\
\hline \multicolumn{3}{|c|}{ Esophageal cancer } \\
\hline \multicolumn{3}{|c|}{ Metastatic non-small cell lung cancer } \\
\hline \multicolumn{3}{|c|}{ Stage IV bladder cancer } \\
\hline \multicolumn{3}{|c|}{ Metastatic renal cell carcinoma } \\
\hline & EBV-positive, advanced stage malignancies & Modified T cells selected for those targeting EBV positive cells \\
\hline & Mesothelin positive solid tumors & CAR T cells to mesothelin with PD-1 knockout \\
\hline Removal of alternative splice site in CEP290 & Leber congenital amaurosis 10 & ZFN-mediated removal of intronic alternative splice site in retinal cells \\
\hline TCR $\alpha$, TCR $\beta$, PD-1 knockout & Various malignancies & $\begin{array}{l}\text { Modified T cells with Cas9-mediated deletions and lentiviral } \\
\text { transduction of NY-ESO-1 targeted TCR }\end{array}$ \\
\hline$\beta \mathrm{TCR} \alpha, \mathrm{TCR} \beta, \beta-2$ microglobin (B2M) knockout & B-cell leukemia & $\begin{array}{l}\text { CD19-CAR modified T cells with CAR delivered by lentivirus and } \\
\text { Cas9 knockout B2M and TCR to create universal T cells }\end{array}$ \\
\hline
\end{tabular}




\subsubsection{Clinical Trials of the Eye Based on CRISPR-Cas9}

Clinical trials of in vivo genome editors have also begun. In all trials, tissues such as the eyes, cervix, and liver have been subjected to experiment. Cas9 was delivered to the eye using Adeno-associated virus vectors (AAV) as a therapy for congenital amaurosis type 10 LBA (LCA10). Because the most frequent LCA10 produces a mutation in the intron of the Centrosomal Protein 290 gene (CEP290) and provides a new binding site that changes the mRNA to form an early stop codon [65], it is a good candidate for the therapy of Cas9. Leber's congenital amaurosis 10 therapy (LCA10) is reported as the first Cas9-related clinical trial (Table 4). This therapy employs two sgRNAs that, when combined, cause partial deletion of the intron or in-version of the partial intron, resulting in normal CEP290 protein production in the patient's cells. Since the eye is an accessible tissue and subretinal injections in mice and mammals have provided stable gene editing, hence successful therapy may also be done in humans [65].

\subsubsection{Limitations of CRISPR-Cas-Based Gene Therapy}

There are many projects related to CRISPR-Cas9 for disease research, and recent results and reports summarize the benefits of CRISPR-Cas9 [66,67]. Before employing CRISPR/Cas9-based gene treatments in humans, their safety and efficacy should be assessed and adjusted [68]. One of the main limitations of this technology is that not all mutation sites play a protospacer adjacent Motif (PAM) role, such that target detection depends entirely on this role. In addition, DNA damage response, delivery vehicle, editing at off-target genomic sites, and immunogenicity are other challenges of using CRISPR-Cas9 for gene therapy. The limitations of CRISPR-Cas9 technology are mainly related to extratarget DNA fracture formation, extra-target mutations, and PAM sequence dependence. Off-target effects are a serious problem in genome editing trials. The CRISP-Cas9 technology has a great chance of causing off-target alternations in human cells compared to other editing approaches $[26,28,62,69]$. Mutations outside the target location can induce gene dysfunction and, in rare cases, cell death. Choosing a suitable target locus possible during the bioinformatics analysis phase improves the effectiveness of the CRISPR-Cas9 system. Combining Cas9-D10A with sgRNA results in hydrolysis of one DNA strand at the target location [70].

\subsection{Plant Science}

Success in plant breeding depends on trait variability as well as overall genetic variation among plant populations. Recently, yield performance and several quality-related properties have been engineered by genome editing [71]. CRISPR-Cas9 has proved useful in crop improvement to increase disease resistance, improve yield, improve nutrition, and aid domestication. These advantageous genetic modifications and others will be discussed in this section.

\subsubsection{Plant Disease Resistance}

Biotic stresses have usually been controlled by the spread of pathogen-resistant varieties and by applying agrochemicals. However, agrochemicals can cause contamination of the environment and negatively impact human health. Plant pathogens are also constantly evolving and can become unresponsive to these controls. Therefore, to create pathogen resistance in plants, resistance genes from wild species were introduced via breeding and established genetic transformation technologies involving large genomics regions [72]. Nonetheless, given the lack of specificity of the large genomic regions being introduced, other less-desirable traits may also be introduced using these approaches to create elite cultivars. Conversely, the CRISPR-Cas9 system provides a more accurate approach to genetic modification. Since first introduced to the field, it has proven to overcome several agricultural challenges including biotic stress resistance, fungal and bacterial disease resistance, and viral resistance [73]. For instance, CRISPR-Cas9 was employed to knockout the mitogen-activated protein kinase-5 (OsMPK5) gene to enhance disease resistance in 
rice [74]. Plant viruses invade a wide range of plants and affect the fertility of crops. As shown in Table 5, the CRISPR-Cas9 system provides a suitable context to develop resistance against both DNA- and RNA-based plant viruses [73].

Table 5. Proven viral resistance in plants introduced via CRISPR-Cas9 against DNA and RNA viruses [73].

\begin{tabular}{ccccc}
\hline Virus & Type of Nucleic Acid & Involved Protein & Plant under Attack & References \\
\hline $\begin{array}{c}\text { Beet severe curly top virus } \\
\text { Bean yellow dwarf virus }\end{array}$ & DNA & Cas9 & Capsicum & Oat \\
DNA & Cas9 & Cruciferous plants, & {$[75]$} \\
Chinese cabbage, & {$[76]$} \\
turnip mosaic virus & RNA & Cas13 & Invading a number of & {$[77]$} \\
Tomato yellow leaf curl virus & DNA & Cas9 & seeds, including tomato & {$[78,79]$} \\
Yellowing virus & RNA & Cas13 & Cucumber & {$[80]$} \\
Zucchini yellow mosaic virus & RNA & Cas13 & Cucumber & {$[81]$} \\
Papaya ring spot mosaic virus & RNA & Cas13 & Cucumber & {$[82]$} \\
\hline
\end{tabular}

As the latest genome editing tool, CRISPR-Cas9 has a key potential in developing bacterial resistance in plants. In several studies, the considerable potential for CRISPR-Cas9 technology has demonstrated to counteract crop bacterial diseases. (Table 6). For example, mutagenesis of the ethylene-responsive factor (ERF) transcription factor gene OsERF922 using this technology enhanced resistance in rice cope with the blast disease. In another case, researchers modified the effector-connection element in the promoter of the Lateral Organ Boundaries-1 gene (LOB) to confer resistance to citrus bacterial canker (CBC) caused by Xanthomanas citri subsp. in Duncan grapefruit [81].

Table 6. Three examples of exploitation of CRISPR-Cas9 to counteract crop bacterial disease.

\begin{tabular}{lllc}
\hline Plant & Targeted Area in Gene & Disease & References \\
\hline Rice & $\begin{array}{l}\text { Mutagenesis of the ERF } \\
\text { Transcription Factor Gene } \\
\text { OsERF922 }\end{array}$ & Blast & {$[72]$} \\
\hline Duncan grapefruit & $\begin{array}{l}\text { Effector-binding element in } \\
\text { the promoter of the Lateral } \\
\text { Organ Boundaries 1 gene }\end{array}$ & $\begin{array}{l}\text { Citrus bacterial } \\
\text { canker (CBC) }\end{array}$ & {$[81]$} \\
\hline Wanjinchen oranges & $\begin{array}{l}\text { (CsLOB1G and CsLOB1-) } \\
\text { alleles }\end{array}$ & $\begin{array}{l}\text { Citrus bacterial } \\
\text { canker (CBC) }\end{array}$ & {$[82]$} \\
\hline
\end{tabular}

\subsubsection{Yield of Crop Plants}

Cereal crops play a key role in human life as food primarily supplying energy. Due to high demand for them, plant breeders have always sought ways to mass produce and generate products with high quality. With the CRISPR-Cas9 technology, it is possible to modify crop characteristics and improve their tolerance to adverse climate conditions and universal threats like drought, salinity, or frost [74]. For instance, to increase tolerance to salinity stress in rice, the $O$. sativa response regulator-22 gene (osRR22) was knocked-out to achieve approximately $65 \%$ mutation in T0 lines [74]. CRISPR-Cas9 was also described to hold potential for enhancing traits like drought or herbicide tolerance in maize [83]. As such, three sgRNAs were designed to target the ZmTMS5 gene in maize and generate mutations in protoplasts, which resulted in edited plants showing bi-allelic modification [74]. Some research have shown the use of CRISPR-based genome editing in plants during the last decade, and a few studies have documented the use of genome editing to ameliorate biotic and abiotic stressors for crop development (Table 7). 
Table 7. Several examples of the application of CRISPR-Cas9 technology in plants against environmental stresses.

\begin{tabular}{|c|c|c|c|c|}
\hline Crop & Method & Target Gene & Stress/Trait & References \\
\hline $\begin{array}{l}\text { A. thatianal } \\
\text { N. benthamiana }\end{array}$ & NHEJ & dsDNA of virus (A7, B7, and C3 regions) & Beet severe curly top virus resistance & [75] \\
\hline N. benthamiana Bean & NHEJ & BeYDV & Yellow dwarf virus (BeYDV) resistance & [76] \\
\hline N. benthamiana & NHEJ & $\begin{array}{l}\text { ORFs and the IR } \\
\text { sequence } \\
\text { sDNA of virus }\end{array}$ & $\begin{array}{c}\text { Tomato yellow leaf curl virus (TYLCV) and } \\
\text { Merremia mosaic virus (MeMV) }\end{array}$ & [77] \\
\hline Rice & NHEJ & OsERF922 (ethylene responsive factor) & Blast Resistance & [78] \\
\hline Cucumber & NHEJ & $\begin{array}{l}\text { eIF4E (eukaryotic translation initiation } \\
\text { factor } 4 \mathrm{E})\end{array}$ & $\begin{array}{l}\text { Cucumber vein yellowing virus (CVYV), } \\
\text { Zucchini } \\
\text { yellow mosaic virus (ZYMV), and } \\
\text { (PRSV-W) }\end{array}$ & [80] \\
\hline A. thaliana & NHEJ & eIF(iso) $4 E$ & Turnip mosaic virus (TuMV) resistance & [84] \\
\hline Rice (IR24) & NHEJ & OsSWEET13 & Bacterial blight disease resistance & [85] \\
\hline Bread wheat & NHEJ & TaMLO-A1, TaMLO-B1, and TaMLOD1 & $\begin{array}{l}\text { Powdery mildew } \\
\text { resistance }\end{array}$ & {$[86]$} \\
\hline Tomato & NHEJ & SIMAPK3 & Drought tolerance & {$[88]$} \\
\hline A. thaliana & HDR & MIR169a & Drought tolerance & [89] \\
\hline A. thaliana & NHEJ & $\begin{array}{c}\text { OST2 (OPEN STOMATA 2) } \\
\text { (AHA1) }\end{array}$ & $\begin{array}{l}\text { Increased stomatal closure in response to } \\
\text { abscisic acid (ABA), }\end{array}$ & [90] \\
\hline Rice & $\begin{array}{l}\text { HDR/ } \\
\text { NHEJ }\end{array}$ & $\begin{array}{l}\text { OsPDS, } \\
\text { OsMPK2, } \\
\text { OsBADH2 }\end{array}$ & Involved in various abiotic stress tolerance & [91] \\
\hline Rice & NHEJ & OsMPK5 & $\begin{array}{l}\text { Various abiotic stress tolerance and disease } \\
\text { resistance }\end{array}$ & [92] \\
\hline Rice & $\begin{array}{l}\text { NHEJ/ } \\
\text { HDR }\end{array}$ & OsMPK2, OsDEP1 & Yield under stress & [93] \\
\hline
\end{tabular}




\subsubsection{Genome Modification for Nutritional Improvement}

As populations grow, the order for high value food crops increases [94]. The CRISPRCas9 system has made it possible to improve crop value and food quality through enhancing their nutritional status. For example, lycopene is a plant nutrient that is widely found in tomato with antioxidant properties and advantageous therapeutic traits. With the success gained in expanding the amount of lycopene content in tomato, it is expected that CRISPR-Cas9 technology may also play a key role in enhancing the micronutrient content of plants [73]. Other examples are presented in Table 8.

Table 8. Application of CRISPR-Cas9 technology in plants for nutritional traits.

\begin{tabular}{|c|c|c|c|c|}
\hline Crop & Method & Target Gene & Stress/Trait & References \\
\hline Rice & NHEJ & 2.5604 gRNA for 12,802 genes & $\begin{array}{l}\text { Creating genome wide } \\
\text { mutant library }\end{array}$ & [95] \\
\hline Maize & NHEJ & $\begin{array}{l}\mathrm{ZmIPK1A} \mathrm{ZmIPK} \\
\text { and ZmMRP4 }\end{array}$ & Phytic acid synthesis & {$[96]$} \\
\hline Wheat & HDR & TaVIT2 & Fe content & [97] \\
\hline Soybean & NHEJ & GmPDS11 and GmPDS18 & Carotenoid biosynthesis & [98] \\
\hline Tomato & NHEJ & Rin & Fruit ripening & [99] \\
\hline Potato & HDR & ALS1 & Herbicide resistance & {$[100]$} \\
\hline Cassava & NHEJ & MePDS & Carotenoid biosynthesis & [101] \\
\hline Rice & NHEJ & 2.5604 gRNA for 12,802 genes & $\begin{array}{c}\text { Creating genome wide } \\
\text { mutant library }\end{array}$ & [95] \\
\hline Maize & NHEJ & $\begin{array}{l}\mathrm{ZmIPK1A} \mathrm{ZmIPK} \\
\text { and ZmMRP4 }\end{array}$ & Phytic acid synthesis & [96] \\
\hline Wheat & HDR & TaVIT2 & Fe content & [97] \\
\hline Soybean & NHEJ & GmPDS11 and GmPDS18 & Carotenoid biosynthesis & [98] \\
\hline Tomato & NHEJ & Rin & Fruit ripening & [99] \\
\hline Potato & HDR & ALS1 & Herbicide resistance & [100] \\
\hline Cassava & NHEJ & MePDS & Carotenoid biosynthesis & [101] \\
\hline
\end{tabular}

\subsubsection{Medicinal Plants}

Medicinal plants may have significant effects in the treatment of various diseases, and they have always been used in traditional medicines. Terpenoids, coumarins, tannins, flavonoid, saponins, phenols, and cardiac glycosides are among the non-nutrient, bioactive, and physiologically active chemicals carried by plants. These phytocompounds are wellknown for their health advantages. CRISPR-Cas9 could be used to modify targeted genes in herbal plants, survey the synthesis of efficacious com-pounds, select characteristics for increased yield, and advance research on biosynthetic pathways and regulatory mechanisms now that the genomes of some medicinal plants have been fully sequenced [75].

\subsection{Animal Breeding}

Due to population-growth driven increasing demand, the production of animalderived food products, especially milk and meat, has increased worldwide. Providing these products is vital for the health and fitness of people [102]. Genome editing technology has made it possible to make precise changes in the animal genome to improve productivity and disease resistance [7]. One of the genes that was first genetically modified in farm animals was myostatin. Changes in this gene can drastically improve economic efficiency of meat production [7]. Farm animals that have been genetically engineered, thus far, include: pig, cattle, sheep, goat, and channel catfish [7]. Nonetheless, because of its global economic value, multiparous nature, and comparatively short generation time, pig is the most genetically modified livestock to date. CRISPR-Cas9 plays a key role in improvement of livestock as the most prominent gene-editing technology today $[103,104]$ (Figure 3). 


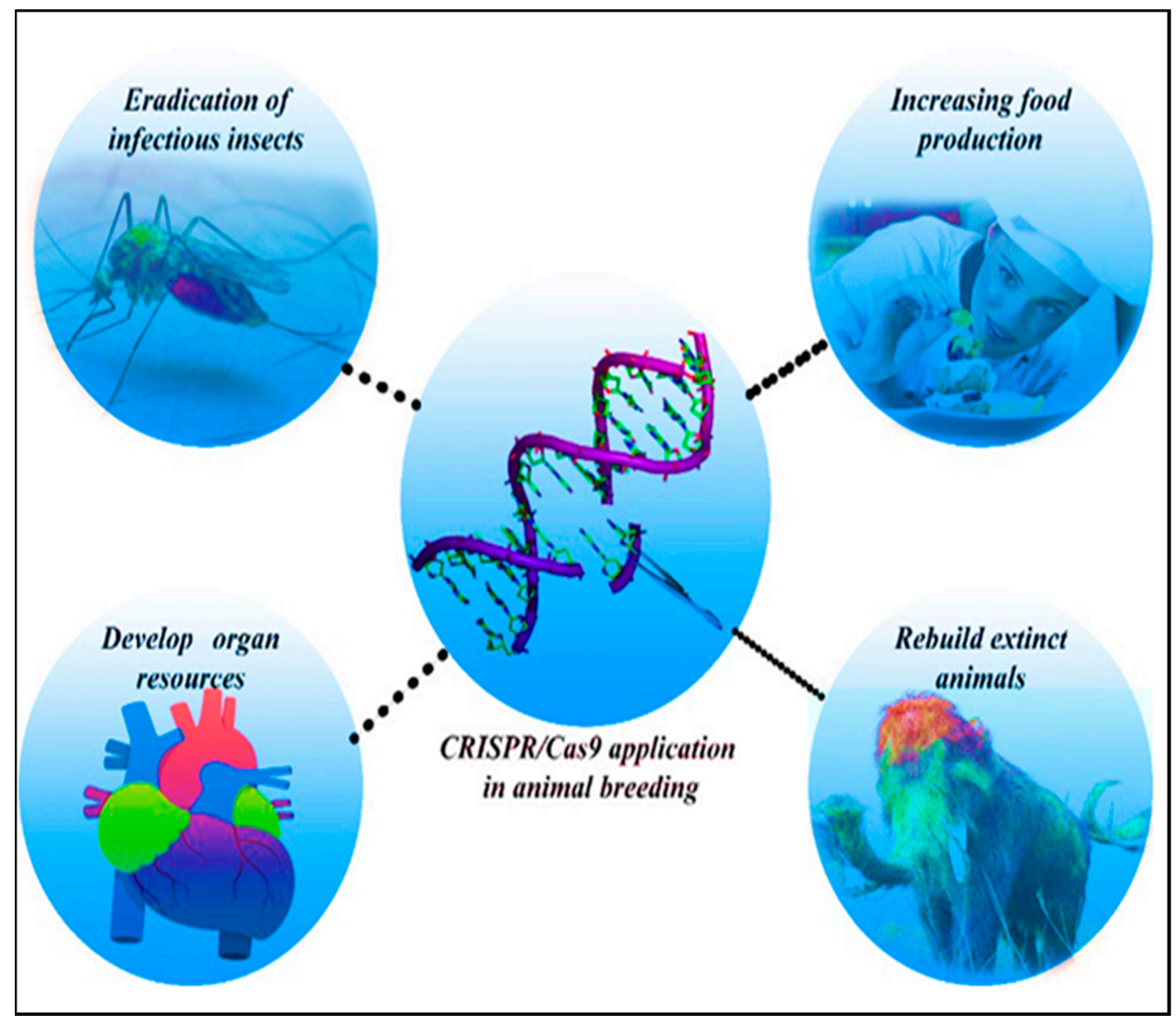

Figure 3. Exploitation of CRISPR-Cas9 in animal breeding and animal models.

This method creates desired changes by either enhancing frequency of favorable alleles or by clearing deleterious alleles [7]. CRISPR-Cas9 has not only helped to increase animal products but also made many contributions to the field of biomedicine by producing transgenic and cloned animals [102]. Genome editing tools, like CRISPR-Cas9 and PiggyBac transposon, could be useful in immunology and vaccine development due to their low risk to human health, such as preventing the transition of viruses [102].

\subsubsection{Modification of Pigs for Xenotransplantation Research}

The transplanting of living organs, tissues, and even living cells from one species to another is known as xenotransplantation or heterologous transplantation. The first serious xenotransplantation attempts were recorded in 1905, when slices of rabbit kidney were implanted into a boy with chronic renal disease [105]. Following that, in the first two decades of the twentieth century, many efforts to utilize organs from pigs, monkeys, and lambs were recorded [105]. Due to their considerable evolutionary distance from humans, pigs (Sus scrofa domesticus) are now the best prospects for organ donation among studied species. Indeed, this evolutionary distance reduces the probability of disease transmission across species [106]. Indeed, in addition to this issue, the short gestation period of pigs is the reason that they were considered as an animal model in clinical trials [107]. One of the most promising breakthroughs in pig-to-human xenotransplantation research is the silencing of porcine endogenous retroviruses (PERVs) and the insertion of the porcine RSAD2 gene into the porcine Rosa26 locus. Niu et al. [16] generated pigs in which all copies of PERVs were inactivated by CRISPR-Cas9 technology. Other examples regarding ap-plication of CRISPR 
technology can be seen in the literature, for example, Ryczek et al. [107], Niu et al. [108], Denner [109], and Hryhorowicz et al. [110].

\subsubsection{Application of CRISPR-Cas9 Technology in Insects}

Most CRISPR-Cas genome editing research so far has relied on the Streptococcus pyogenes Cas9 nuclease, which can recognize the PAM sequence NGG [111]. Insects are the most numerous creatures found in nature. As a result, ongoing research efforts have added to the body of insect genomic information for species including Drosophila melanogaster Meigen, Tribolium castaneum, Bombyx mori L., Apis mellifera L., Nasonia vitripennis Walker, Acyrthosiphon pisum, and Plutella xylostella L. [112]. Insect uses of CRISPR-Cas9 are becoming more common, namely in Drosophila melanogaster, Bombyx mori, and Aedes aegypti. This method is not only becoming increasingly prominent in functional genomics research [113], but it is also being used as a tool for pest bug and vector-borne disease control $[113,114]$. Due to its capacity to have a wide variety of genetic tools, Drosophila has been regarded as one of the greatest insect models for the study of eukaryotic biology, including human development and illness in insect research. Gratz et al. [115] started the Drosophila CRISPRCas9 journey by deleting a $4.6 \mathrm{~kb}$ segment of the yellow gene using two gRNAs targeting the $5^{\prime}$ and $3^{\prime}$ ends of the source, respectively, in 2013. CRISPR-Cas9 is also being tested in other insect species, according to researchers (Table 9).

Table 9. Applications of CRISPR-Cas9 in insects.

\begin{tabular}{|c|c|c|c|c|c|}
\hline Species & Targeted Genes & Strategy & $\begin{array}{c}\text { Germline Transmission } \\
\text { Rate (\%) }\end{array}$ & $\begin{array}{c}\text { G1 Mutation Rate } \\
(\%)\end{array}$ & References \\
\hline \multirow[t]{4}{*}{ Drosophila spec. } & yellow, whit & mRNA INJ & $0-79$ & $0-34.5$ & [116] \\
\hline & $\begin{array}{l}\text { CG4221, CG5961, } \\
\text { Chameau }\end{array}$ & $\begin{array}{l}\text { mRNA INJ with } \\
\text { donor }\end{array}$ & $8.1-26.7$ & $2.7-10.4$ & [117] \\
\hline & yellow & DNA INJ with donor & 5.9-20.7 & $0.25-1.37$ & [115] \\
\hline & yellow & Rapid INJ with donor & $8-53$ & 15 & [118] \\
\hline \multirow[t]{2}{*}{ Bombyx mori } & BmBLOS2 & mRNA INJ & 95.5 & 35.6 & [119] \\
\hline & $\begin{array}{l}\text { th, re, fl, yellow-e, } \\
\text { kynu, ebony }\end{array}$ & DNA INJ & $5.7-18.9$ & ND & [120] \\
\hline Aedes aegypti & ECFP & $\begin{array}{l}\text { mRNA INJ + DNA } \\
\text { INJ }\end{array}$ & 0 & 5.5 & [121] \\
\hline Daphnia magna & eyeless & mRNA INJ & $18-47$ & 8.2 & [122] \\
\hline Tribolium castaneum & eGFP1 & $\begin{array}{l}\text { mRNA INJ + DNA } \\
\text { INJ with donor }\end{array}$ & $55-80$ & $71-100$ & [123] \\
\hline $\begin{array}{l}\text { Papilio xuthus, } P \text {. } \\
\text { machaon }\end{array}$ & $\begin{array}{l}\text { abdominal-B, ebony, } \\
\text { frizzled }\end{array}$ & mRNA INJ & $18.33-90.85$ & ND & [124] \\
\hline
\end{tabular}

NIJ and ND indicate injection and not determined, respectively.

\section{Conclusions}

The CRISPR-Cas9 technology is a new and purposeful method in genome editing that has recently surpassed other methods due to its outstanding advantages. So that, it has significantly contributed to all fields of life science, including medicine, plant breeding, and animal breeding, also expanding researchers' understanding of the basis of gene diversity and gene editing. Given its current central role in this landscape, ongoing research will likely focus on improving this technology further to enhance its specificity and efficiency.

Author Contributions: A.P.-A. and A.E. conceived the idea; K.T., F.K., and A.P.-A. wrote the manuscript and prepared the figures; L.S., A.E., and K.T. collected information and prepared the Table. A.P.-A. and P.P. revised the manuscript. All authors have read and agreed to the published version of the manuscript.

Funding: This research received no external funding. 
Institutional Review Board Statement: Not applicable.

Informed Consent Statement: Not applicable.

Data Availability Statement: Not applicable.

Conflicts of Interest: The authors declare no conflict of interest.

\section{References}

1. Yang, G.; Huang, X. Methods and applications of CRISPR/Cas system for genome editing in stem cells. Cell Regen. $2019,8,33-41$. [CrossRef]

2. Manghwar, H.; Lindsey, K.; Zhang, X.; Jin, S. CRISPR/Cas System: Recent Advances and Future Prospects for Genome Editing Trends Plant Sci. 2019, 24, 1102-1125. [CrossRef]

3. Mirza, Z.; Karim, S. Advancements in CRISPR/Cas9 technology-focusing on cancer therapeutics and beyond. Semin. Cell Dev. Biol. 2019, 96, 13-21. [CrossRef]

4. Mehravar, M.; Shirazi, A.; Nazari, M.; Banan, M. Mosaicism in CRISPR/Cas9-mediated genome editing. Dev. Biol. 2019, 445, 156-162. [CrossRef]

5. Abdelrahman, M.; Al-Sadi, A.M.; Pour-Aboughadareh, A.; Burritt, D.J.; Tran, L.-S.P. Genome editing using CRISPR/Cas9-targeted mutagenesis: An opportunity for yield improvements of crop plants grown under environmental stresses. Plant Physiol. Biochem. 2018, 131, 31-36. [CrossRef] [PubMed]

6. Martinez-Lage, M.; Puig-Serra, P.; Menendez, P.; Torres-Ruiz, R.; Rodriguez-Perales, S. CRISPR/Cas9 for Cancer Therapy: Hopes and Challenges. Biomedicines 2018, 6, 105. [CrossRef]

7. Raguz, N.; Lukic, B. Potential gain of genome editing for improved animal breeding. In Proceedings of the 55th Croatian \& 15 th International Symposium on Agriculture, Vodice, Croatia, 16-21 February 2020.

8. Ishino, Y.; Shinagawa, H.; Makino, K.; Amemura, M.; Nakata, A. Nucleotide sequence of the iap gene, responsible for alkaline phosphatase isozyme conversion in Escherichia coli, and identification of the gene product. J. Bacteriol. 1987, 169, 5429-5433. [CrossRef] [PubMed]

9. Wright, A.V.; Nunez, J.K.; Doudna, J.A. Biology and applications of CRISPR systems: Harnessing nature's toolbox for genome engineering. Cell 2016, 164, 29-44. [CrossRef] [PubMed]

10. Doudna, J.A.; Charpentier, E. Genome editing. The new frontier of genome engineering with CRISPR-Cas9. Science 2014, 346, 1258096. [CrossRef] [PubMed]

11. Barrangou, R.; Fremaux, C.; Deveau, H.; Richards, M.; Boyaval, P.; Moineau, S.; Romero, D.A.; Horvath, P. CRISPR provides acquired resistance against viruses in prokaryotes. Science 2007, 315, 1709-1712. [CrossRef] [PubMed]

12. Jiang, F.; Doudna, J.A. CRISPR-Cas9 Structures and Mechanisms. Annu. Rev. Biophys. 2017, 46, 505-529. [CrossRef]

13. Cong, L.; Ran, F.A.; Cox, D.; Lin, S.; Barretto, R.; Habib, N.; Hsu, P.D.; Wu, X.; Jiang, W.; Marraffini, L.A. Multiplex genome engineering using CRISPR/Cas systems. Science 2013, 339, 819-823. [CrossRef]

14. Mali, P.; Yang, L.; Esvelt, K.M.; Aach, J.; Guell, M.; DiCarlo, J.E.; Norville, J.E.; Church, G.M. RNA-guided human genome engineering via Cas9. Science 2013, 339, 823-826. [CrossRef] [PubMed]

15. Jinek, M.; East, A.; Cheng, A.; Lin, S.; Ma, E.; Doudna, J. RNA-programmed genome editing in human cells. eLife 2013 , 2 , e00471. [CrossRef] [PubMed]

16. Zhang, Y.; Karakikes, I. Translating genomic insights into cardiovascular medicines: Opportunities and challenges of CRISPR-Cas9. Trends Cardiovasc. Med. 2020. [CrossRef]

17. Sun, J.-Y.; Hu, H.-B.; Cheng, Y.-X.; Lu, X.-J. CRISPR in medicine: Applications and challenges. Brief. Funct. Genom. 2020, 19, 151-153. [CrossRef]

18. Ahmad, S.; Wei, X.; Sheng, Z.; Hu, P.; Tang, S. CRISPR/Cas9 for development of disease resistance in plants: Recent progress, limitations and future prospects. Brief. Funct. Genom. 2020, 19, 26-39. [CrossRef]

19. Tahir, T.; Ali, Q.; Rashid, M.; Malik, A. The journey of CRISPR-Cas9 from bacterial defense mechanism to a gene editing tool in both animals and plants. Biol. Clin. Sci. Res. J. 2020, 2020, e017.

20. Hundleby, P.A.C.; Harwood, W.A. Impacts of the EU GMO regulatory framework for plant genome editing. Food Energy Secur. 2019, 8, e00161. [CrossRef]

21. Hirsch, F.; Iphofen, R.; Koporc, Z. Ethics assessment in research proposals adopting CRISPR technology. Biochem. Med. 2019, 29, 020202. [CrossRef]

22. Cai, L.; Zheng, L.A.; He, L. The forty years of medical genetics in China. J. Genet. Genom. 2018, 45, 569-582. [CrossRef] [PubMed]

23. Memi, F.; Ntokou, A.; Papangeli, I. CRISPR/Cas9 gene-editing: Research technologies, clinical applications and ethical considerations. Semin. Perinatol. 2018, 42, 487-500. [CrossRef] [PubMed]

24. Rodriguez, E. Ethical issues in genome editing using Crispr/Cas9 system. J. Clin. Res. Bioeth. 2016, 7, 266.

25. Esvelt, K.M.; Smidler, A.L.; Catteruccia, F.; Church, G.M. Concerning RNA-guided gene drives for the alteration of wild populations. eLife 2014, 3, e03401. [CrossRef]

26. Shinwari, Z.K.; Tanveer, F.; Khalil, A.T. Ethical issues regarding CRISPR-mediated genome editing. Curr. Issues Mol. Biol. 2017, 26, 103-110.

27. Polcz, S.; Lewis, A. CRISPR-Cas9 and the non-germline non-controversy. J. Law Biosci. 2016, 3, 413-425. [CrossRef] 
28. Rodriguez, E. Ethical issues in genome editing for non-human organisms using CRISPR/Cas9 system. J. Clin. Res. Bioeth. 2017, 8, 10-4172. [CrossRef]

29. Eriksson, S.; Jonas, E.; Rydhmer, L.; Röcklinsberg, H. Invited review: Breeding and ethical perspectives on genetically modified and genome edited cattle. J. Dairy Sci. 2018, 101, 1-17. [CrossRef] [PubMed]

30. Koplin, J.J. Human-animal chimeras: The moral insignificance of uniquely human capacities. Hastings Cent. Rep. 2019, 49, $23-32$. [CrossRef]

31. Degrazia, D. Human-animal chimeras, "human" cognitive capacities, and moral status. Hastings Cent. Rep. 2019, 49, 33-34. [CrossRef]

32. de Graeff, N.; Jongsma, K.R.; Johnston, J.; Hartley, S.; Bredenoord, A.L. The ethics of genome editing in non-human animals: A systematic review of reasons reported in the academic literature. Philos. Trans. R. Soc. B 2019, 374, 20180106. [CrossRef] [PubMed]

33. Otieno, M.O. CRISPR-Cas9 human genome editing: Challenges, ethical concerns and implications. J. Clin. Res. Bioeth. 2015, 6, 253-255.

34. Duardo-Sanchez, A. CRISPR-Cas in medicinal chemistry: Applications and regulatory concerns. Curr. Top. Med. Chem. 2017, 17, 3308-3315. [CrossRef]

35. Greene, M.; Master, Z. Ethical issues of using CRISPR technologies for research on military enhancement. J. Bioethical Inq. 2018, 15, 327-335. [CrossRef]

36. Sherkow, J.S. The CRISPR patent landscape: Past, present, and future. CRISPR J. 2018, 1, 5-9. [CrossRef]

37. Cathomen, T.; Schüle, S.; Schüßler-Lenz, M.; Abou-El-Enein, M. The human genome editing race: Loosening regulatory standards for commercial advantage? Trends Biotechnol. 2019, 37, 120-123. [CrossRef]

38. Lyu, C.; Shen, J.; Wang, R.; Gu, H.; Zhang, J.; Xue, F.; Liu, X.; Liu, W.; Fu, R.; Zhang, L.; et al. Targeted genome engineering in human induced pluripotent stem cells from patients with hemophilia B using the CRISPR-Cas9 system. Stem Cell Res. Ther. 2018, 9, 92. [CrossRef]

39. Shimo, T.; Hosoki, K.; Nakatsuji, Y.; Yokota, T.; Obika, S. A novel human muscle cell model of Duchenne muscular dystrophy created by CRISPR/Cas9 and evaluation of antisense-mediated exon skipping. J. Hum. Genet. 2018, 63, 365-375. [CrossRef]

40. Egorova, T.V.; Zotova, E.D.; Reshetov, D.A.; Polikarpova, A.V.; Vassilieva, S.G.; Vlodavets, D.V.; Gavrilov, A.A.; Ulianov, S.V.; Buchman, V.L.; Deykin, A.V. CRISPR/Cas9-generated mouse model of Duchenne muscular dystrophy recapitulating a newly identified large $430 \mathrm{~kb}$ deletion in the human DMD gene. Dis. Models Mech. 2019, 12. [CrossRef]

41. Long, C.; Amoasii, L.; Mireault, A.A.; McAnally, J.R.; Li, H.; Sanchez-Ortiz, E.; Bhattacharyya, S.; Shelton, J.M.; Bassel-Duby, R.; Olson, E.N. Postnatal genome editing partially restores dystrophin expression in a mouse model of muscular dystrophy. Science 2016, 351, 400-403. [CrossRef]

42. Nelson, C.E.; Hakim, C.H.; Ousterout, D.G.; Thakore, P.I.; Moreb, E.A.; Rivera, R.M.C.; Madhavan, S.; Pan, X.; Ran, F.A.; Yan, W.X.; et al. In vivo genome editing improves muscle function in a mouse model of Duchenne muscular dystrophy. Science 2016, 351, 403-407. [CrossRef]

43. Tabebordbar, M.; Zhu, K.; Cheng, J.K.W.; Chew, W.L.; Widrick, J.J.; Yan, W.X.; Maesner, C.C.; Wu, E.Y.; Xiao, R.; Ran, F.A.; et al. In vivo gene editing in dystrophic mouse muscle and muscle stem cells. Science 2016, 351, 407-411. [CrossRef]

44. Bjursell, M.; Porritt, M.J.; Ericson, E.; Taheri-Ghahfarokhi, A.; Clausen, M.; Magnusson, L.; Admyre, T.; Nitsch, R.; Mayr, L.; Aasehaug, L.; et al. Therapeutic Genome Editing With CRISPR/Cas9 in a Humanized Mouse Model Ameliorates alpha1antitrypsin Deficiency Phenotype. EBioMedicine 2018, 29, 104-111. [CrossRef]

45. Song, C.-Q.; Wang, D.; Jiang, T.; O'Connor, K.; Tang, Q.; Cai, L.; Li, X.; Weng, Z.; Yin, H.; Gao, G.; et al. In Vivo Genome Editing Partially Restores Alpha1-Antitrypsin in a Murine Model of AAT Deficiency. Hum. Gene Ther. 2018, 29, 853-860. [CrossRef]

46. Gao, X.; Tao, Y.; Lamas, V.; Huang, M.; Yeh, W.-H.; Pan, B.; Hu, Y.-J.; Hu, J.H.; Thompson, D.B.; Shu, Y.; et al. Treatment of autosomal dominant hearing loss by in vivo delivery of genome editing agents. Naure 2018, 553, 217-221. [CrossRef]

47. György, B.; Nist-Lund, C.; Pan, B.; Asai, Y.; Karavitaki, K.D.; Kleinstiver, B.P.; Garcia, S.; Zaborowski, M.P.; Solanes, P.; Spataro, S.; et al. Allele-specific gene editing prevents deafness in a model of dominant progressive hearing loss. Nat. Med. 2019, 25, 1123-1130. [CrossRef]

48. Xu, S.; Luk, K.; Yao, Q.; Shen, A.H.; Zeng, J.; Wu, Y.; Luo, H.-Y.; Brendel, C.; Pinello, L.; Chui, D.H.K.; et al. Editing aberrant splice sites efficiently restores $\beta$-globin expression in $\beta$-thalassemia. Blood 2019, 133, 2255-2262. [CrossRef]

49. Canver, M.C.; Smith, E.C.; Sher, F.; Pinello, L.; Sanjana, N.; Shalem, O.; Chen, D.D.; Schupp, P.G.; Vinjamur, D.; Garcia, S.; et al. BCL11A enhancer dissection by Cas9-mediated in situ saturating mutagenesis. Nature 2015, 527, 192-197. [CrossRef]

50. Wu, Y.; Zeng, J.; Roscoe, B.P.; Liu, P.; Yao, Q.; Lazzarotto, C.R.; Clement, M.K.; Cole, M.; Luk, K.; Baricordi, C.; et al. Highly efficient therapeutic gene editing of human hematopoietic stem cells. Nat. Med. 2019, 25, 776-783. [CrossRef]

51. Park, S.H.; Lee, C.M.; Dever, D.P.; Davis, T.H.; Camarena, J.; Srifa, W.; Zhang, Y.; Paikari, A.; Chang, A.K.; Porteus, M.H.; et al. Highly efficient editing of the beta-globin gene in patient-derived hematopoietic stem and progenitor cells to treat sickle cell disease. Nucleic Acids Res. 2019, 47, 7955-7972. [CrossRef]

52. Castaño, J.; Herrero, A.B.; Bursen, A.; González, F.; Marschalek, R.; Gutierrez, N.; Menendez, P. Expression of MLL-AF4 or AF4-MLL fusions does not impact the efficiency of DNA damage repair. Oncotarget 2016, 7, 30440-30452. [CrossRef]

53. Reimer, J.; Knoess, S.; Labuhn, M.; Charpentier, E.M.; Goehring, G.; Schlegelberger, B.; Klusmann, J.-H.; Heckl, D. CRISPRCas9induced $\mathrm{t}(11 ; 19)$ /MLL-ENL translocations initiate leukemia in human hematopoietic progenitor cells in vivo. Haematologica 2017, 102, 1558-1566. [CrossRef] 
54. Heckl, D.; Kowalczyk, M.S.; Yudovich, D.; Belizaire, R.; Puram, R.V.; McConkey, M.E.; Thielke, A.; Aster, J.C.; Regev, A.; Ebert, B.L. Generation of mouse models of myeloid malignancy with combinatorial genetic lesions using CRISPR-Cas9 genome editing. Nat. Biotechnol. 2014, 32, 941-946. [CrossRef]

55. Shi, J.; Wang, E.; Milazzo, J.P.; Wang, Z.; Kinney, J.B.; Vakoc, C.R. Discovery of cancer drug targets by CRISPR-Cas9 screening of protein domains. Nat. Biotechnol. 2015, 33, 661-667. [CrossRef]

56. Xu, P.; Tong, Y.; Liu, X.-Z.; Wang, T.-T.; Cheng, L.; Wang, B.-Y.; Lv, X.; Huang, Y.; Liu, D.-P. Both TALENs and CRISPR/Cas9 directly target the HBB IVS2-654 (C>T) mutation in $\beta$-thalassemia-derived iPSCs. Sci. Rep. 2015, 5, 12065. [CrossRef]

57. Antony, J.S.; Latifi, N.; Haque, A.K.M.A.; Lamsfus-Calle, A.; Daniel-Moreno, A.; Graeter, S.; Baskaran, P.; Weinmann, P.; Mezger M.; Handgretinger, R.; et al. Gene correction of HBB mutations in CD34 ${ }^{+}$hematopoietic stem cells using Cas9 mRNA and ssODN donors. Mol. Cell. Pediatrics 2018, 5, 9. [CrossRef]

58. Lin, S.-R.; Yang, H.-C.; Kuo, Y.-T.; Liu, C.-J.; Yang, T.-Y.; Sung, K.-C.; Lin, Y.-Y.; Wang, H.-Y.; Wang, C.-C.; Shen, Y.-C.; et al. The CRISPR/Cas9 system facilitates clearance of the intrahepatic HBV templates in vivo. Mol. Ther. Nucleic Acids. 2014, 3, e186. [CrossRef]

59. Hazafa, A.; Mumtaz, M.; Farooq, M.F.; Bilal, S.; Chaudhry, S.N.; Firdous, M.; Naeem, H.; Ullah, M.O.; Yameen, M.; Mukhtiar, M.S.; et al. CRISPR/Cas9: A powerful genome editing technique for the treatment of cancer cells with present challenges and future directions. Life Sci. 2020, 263, 118525. [CrossRef]

60. U.S. National Library of Medicine. Available online: https:/ / clinicaltrials.gov / (accessed on 22 May 2021).

61. He, S. The first human trial of CRISPR-based cell therapy clears safety concerns as new treatment for late-stage lung cancer. Signal Transduct. Target. Ther. 2020, 5, 168. [CrossRef]

62. Hirakawa, M.P.; Krishnakumar, R.; Timlin, J.A.; Carney, J.P.; Butler, K.S. Gene editing and CRISPR in the clinic: Current and future perspectives. Biosci. Rep. 2020, 40, BSR20200127. [CrossRef]

63. Frangoul, H.; Altshuler, D.; Cappellini, M.D.; Chen, Y.-S.; Domm, J.; Eustace, B.K.; Foell, J.; De La Fuente, J.; Grupp, S.; Handgretinger, R.; et al. CRISPR-Cas9 Gene Editing for Sickle Cell Disease and $\beta$-Thalassemia. N. Engl. J. Med. 2021, 384, 252-260. [CrossRef]

64. Lu, Y.; Xue, J.; Deng, T.; Zhou, X.; Yu, K.; Deng, L.; Huang, M.; Yi, X.; Liang, M.; Wang, Y.; et al. Safety and feasibility of CRISPR-edited T cells in patients with refractory non-small-cell lung cancer. Nat. Med. 2020, 26, 732-740. [CrossRef]

65. Maeder, M.L.; Stefanidakis, M.; Wilson, C.J.; Baral, R.; Barrera, L.A.; Bounoutas, G.S.; Bumcrot, D.; Chao, H.; Ciulla, D.M.; DaSilva, J.A.; et al. Development of a gene-editing approach to restore vision loss in Leber congenital amaurosis type 10. Nat. Med. 2019, 25, 229-233. [CrossRef]

66. Molla, K.A.; Yang, Y. CRISPR/Cas-Mediated Base Editing: Technical Considerations and Practical Applications. Trends Biotechnol. 2019, 37, 1121-1142. [CrossRef]

67. Knott, G.J.; Doudna, J.A. CRISPR-Cas guides the future of genetic engineering. Science 2018, 361, 866. [CrossRef] [PubMed]

68. Rich, K.; Terry, S.F. CRISPR-Cas9: New Heights, New Hesitations. Genet. Test. Mol. Biomark. 2018, 22, 635-636. [CrossRef] [PubMed]

69. Fu, Y.; Foden, J.A.; Khayter, C.; Maeder, M.L.; Reyon, D.; Joung, J.K.; Sander, J.D. High-frequency off-target mutagenesis induced by CRISPR-Cas nucleases in human cells. Nat. Biotechnol. 2013, 31, 822-826. [CrossRef]

70. Cui, Y.; Liao, X.; Peng, S.; Tang, T.; Huang, C.; Yang, C. OffScan: A universal and fast CRISPR off-target sites detection tool. BMC Genom. 2020, 21, 872. [CrossRef]

71. Jung, C.; Capistrano-Gossmann, G.; Braatz, J.; Sashidhar, N.; Melzer, S. Recent developments in genome editing and applications in plant breeding. Plant Breed. 2018, 137, 1-9. [CrossRef]

72. Wang, F.; Wang, C.; Liu, P.; Lei, C.; Hao, W.; Gao, Y.; Liu, Y.G.; Zhao, K. Enhanced Rice Blast Resistance by CRISPR/Cas9-Targeted Mutagenesis of the ERF transcription factor gene OsERF922. PLoS ONE 2016, 11, e0154027. [CrossRef]

73. Pillay, M. Genome Editing Technologies for Crop Improvement. In Quantitative Genetics, Genomics and Plant Breeding, 2nd ed.; CABI: Boston, MA, USA, 2020; pp. 33-44.

74. Hillary, V.E.; Ceasar, S.A. Application of CRISPR/Cas9 Genome Editing System in Cereal Crops. Open Biotechnol. J. 2019, 13, 173-179. [CrossRef]

75. Ji, X.; Zhang, H.; Zhang, Y.; Wang, Y.; Gao, C. Establishing a CRISPR-Cas-like immune system conferring DNA virus resistance in plants. Nat. Plants 2015, 1, 15144. [CrossRef]

76. Baltes, N.J.; Hummel, A.W.; Konecna, E.; Cegan, R.; Bruns, A.N.; Bisaro, D.M.; Voytas, D.F. Conferring resistance to geminiviruses with the CRISPR-Cas prokaryotic immune system. Nat. Plants 2015, 1, 15145. [CrossRef]

77. Aman, R.; Ali, Z.; Butt, H.; Mahas, A.; Aljedaani, F.; Khan, M.Z.; Ding, S.; Mahfouz, M. RNA virus interference via CRISPR/Cas13a system in plants. Genome Biol. 2018, 19, 1. [CrossRef]

78. Ali, Z.; Abulfaraj, A.; Idris, A.; Ali, S.; Tashkandi, M.; Mahfouz, M.M. CRISPR/Cas9-mediated viral interference in plants. Genome Biol. 2015, 16, 238. [CrossRef]

79. Mahas, A.; Mahfouz, M. Engineering virus resistance via CRISPR-Cas systems. Curr. Opin. Virol. 2018, 32, 1-8. [CrossRef]

80. Chandrasekaran, J.; Brumin, M.; Wolf, D.; Leibman, D.; Klap, C.; Pearlsman, M.; Sherman, A.; Arazi, T.; Gal-On, A. Development of broad virus resistance in non-transgenic cucumber using CRISPR/Cas9 technology. Mol. Plant Pathol. 2016, 17, 1140-1153. [CrossRef] 
81. Jia, H.; Zhang, Y.; Orbović, V.; Xu, J.; White, F.F.; Jones, J.B.; Wang, N. Genome editing of the disease susceptibility gene CsLOB1 in citrus confers resistance to citrus canker. Plant Biotechnol. J. 2017, 15, 817-823. [CrossRef]

82. Peng, A.; Chen, S.; Lei, T.; Xu, L.; He, Y.; Wu, L.; Yao, L.; Zou, X. Engineering canker-resistant plants through CRISPR/Cas9targeted editing of the susceptibility gene CsLOB1 promoter in citrus. Plant Biotechnol. J. 2017, 15, 1509-1519. [CrossRef]

83. Chilcoat, D.; Liu, Z.-B.; Sander, J. Use of CRISPR/Cas9 for Crop Improvement in Maize and Soybean. In Progress in Molecular Biology and Translational Science; Weeks, D.P., Yang, B., Eds.; Academic Press: Cambridge, MA, USA, 2017; Volume 149, pp. 27-46.

84. Pyott, D.E.; Sheehan, E.; Molnar, A. Engineering of CRISPR/Cas9-mediated potyvirus resistance in transgene-free Arabidopsis plants. Mol. Plant Pathol. 2016, 17, 1276-1288. [CrossRef]

85. Zhou, J.; Peng, Z.; Long, J.; Sosso, D.; Liu, B.; Eom, J.-S.; Huang, S.; Liu, S.; Cruz, C.V.; Frommer, W.; et al. Gene targeting by the TAL effector PthXo2 reveals cryptic resistance gene for bacterial blight of rice. Plant J. 2015, 82, 632-643. [CrossRef]

86. Wang, Y.; Cheng, X.; Shan, Q.; Zhang, Y.; Liu, J.; Gao, C.; Qiu, J.-L. Simultaneous editing of three homoeoalleles in hexaploid bread wheat confers heritable resistance to powdery mildew. Nat. Biotechnol. 2014, 32, 947-951. [CrossRef]

87. Shi, J.; Gao, H.; Wang, H.; Lafitte, H.R.; Archibald, R.L.; Yang, M.; Hakimi, S.M.; Mo, H.; Habben, J.E. ARGOS8 variants generated by CRISPR-Cas9 improve maize grain yield under field drought stress conditions. Plant Biotechnol. J. 2017, 15, 207-216. [CrossRef]

88. Wang, L.; Chen, L.; Li, R.; Zhao, R.; Yang, M.; Sheng, J.; Shen, L. Reduced drought tolerance by CRISPR/Cas9-mediated SIMAPK3 mutagenesis in tomato plants. J. Agric. Food Chem. 2017, 65, 8674-8682. [CrossRef]

89. Zhao, Y.; Zhang, C.; Liu, W.; Gao, W.; Liu, C.; Song, G.; Li, W.-X.; Mao, L.; Chen, B.; Xu, Y.; et al. An alternative strategy for targeted gene replacement in plants using a dual-sgRNA/Cas9 design. Sci. Rep. 2016, 6, 23890. [CrossRef] [PubMed]

90. Osakabe, Y.; Watanabe, T.; Sugano, S.S.; Ueta, R.; Ishihara, R.; Shinozaki, K.; Osakabe, K. Optimization of CRISPR/Cas9 genome editing to modify abiotic stress responses in plants. Sci. Rep. 2016, 6, 26685. [CrossRef] [PubMed]

91. Shan, Q.; Wang, Y.; Li, J.; Zhang, Y.; Chen, K.; Liang, Z.; Zhang, K.; Liu, J.; Xi, J.J.; Qiu, J.-L.; et al. Targeted genome modification of crop plants using a CRISPR-Cas system. Nat. Biotechnol. 2013, 31, 686-688. [CrossRef]

92. Xie, K.; Yang, Y. RNA-guided genome editing in plants using a CRISPR-Cas system. Mol. Plant 2013, 6, 1975-1983. [CrossRef] [PubMed]

93. Shan, Q.; Wang, Y.; Li, J.; Gao, C. Genome editing in rice and wheat using the CRISPR/Cas system. Nat. Protoc. 2014, 9, 2395-2410. [CrossRef]

94. Zhang, H.; Zhang, J.; Wei, P.; Zhang, B.; Gou, F.; Feng, Z.; Mao, Y.; Yang, L.; Zhang, H.; Xu, N.; et al. The CRISPR/Cas9 system produces specific and homozygous targeted gene editing in rice in one generation. Plant Biotechnol. J. 2014, 12, 797-807. [CrossRef] [PubMed]

95. Xu, H.; Xiao, T.; Chen, C.-H.; Li, W.; Meyer, C.A.; Wu, Q.; Wu, D.; Cong, L.; Zhang, F.; Liu, J.S.; et al. Sequence determinants of improved CRISPR sgRNA design. Genome Res. 2015, 25, 1147-1157. [CrossRef] [PubMed]

96. Mao, X.; Zheng, Y.; Xiao, K.; Wei, Y.; Zhu, Y.; Cai, Q.; Chen, L.; Xie, H.; Zhang, J. OsPRX2 contributes to stomatal closure and improves potassium deficiency tolerance in rice. Biochem. Biophys. Res. Commun. 2018, 495, 461-467. [CrossRef] [PubMed]

97. Meng, Y.; Hou, Y.; Wang, H.; Ji, R.; Liu, B.; Wen, J.; Niu, L.; Lin, H. Targeted mutagenesis by CRISPR/Cas9 system in the model legume Medicago truncatula. Plant Cell Rep. 2017, 36, 371-374. [CrossRef]

98. Liang, Z.; Zhang, K.; Chen, K.; Gao, C. Targeted mutagenesis in Zea mays using TALENs and the CRISPR/Cas system. J. Genet. Genom. 2014, 41, 63-68. [CrossRef]

99. Connorton, J.M.; Jones, E.R.; Rodriguez-Ramiro, I.; Fairweather-Tait, S.; Uauy, C.; Balk, J. Wheat vacuolar iron transporter TaVIT2 transports Fe and Mn and is effective for biofortification. Plant Physiol. 2017, 174, 2434-2444. [CrossRef]

100. Du, H.; Zeng, X.; Zhao, M.; Cui, X.; Wang, Q.; Yang, H.; Cheng, H.; Yu, D. Efficient targeted mutagenesis in soybean by TALENs and CRISPR/Cas9. J. Biotechnol. 2016, 217, 90-97. [CrossRef]

101. Ito, Y.; Nishizawa-Yokoi, A.; Endo, M.; Mikami, M.; Toki, S. CRISPR/Cas9-mediated mutagenesis of the RIN locus that regulates tomato fruit ripening. Biochem. Biophys. Res. Commun. 2015, 467, 76-82. [CrossRef]

102. Butler, N.M.; Baltes, N.J.; Voytas, D.F.; Douches, D.S. Geminivirus-mediated genome editing in potato (Solanum tuberosum L.) using sequence-specific nucleases. Front. Plant Sci. 2016, 7, 1045. [CrossRef]

103. Odipio, J.; Alicai, T.; Ingelbrecht, I.; Nusinow, D.A.; Bart, R.; Taylor, N.J. Efficient CRISPR/Cas9 genome editing of phytoene desaturase in cassava. Front. Plant Sci. 2017, 8, 1780. [CrossRef]

104. Funahashi, H. Animal Biotechnology Roles in Livestock Production. IOP Conf. Ser. Earth Environ. Sci. 2020, $465,012001$. [CrossRef]

105. Proudfoot, C.; Lillico, S.; Tait-Burkard, C. Genome editing for disease resistance in pigs and chickens. Anim. Front. 2019, 9, 6-12. [CrossRef] [PubMed]

106. Shrock, E.; Guell, M. CRISPR in animals and animal models. Prog. Mol. Biol. Transl. Sci. 2017, 152, 95-114.

107. Bailey, L.L.; Nehlsen-Cannarella, S.L.; Concepcion, W.; Jolley, W.B. Baboon-to-human cardiac xenotransplantation in a neonate. JAMA 1985, 254, 3321-3329. [CrossRef] [PubMed]

108. Dooldeniya, M.D.; Warrens, A.N. Xenotransplantation: Where are we today? J. R. Soc. Med. 2003, 96, 111-117. [CrossRef]

109. Ryczek, N.; Hryhorowicz, M.; Zeyland, J.; Lipi'nski, D.; Słomski, R. CRISPR/Cas technology in pig-to-human Xenotransplantation RESEARCH. Int. J. Mol. Sci. 2021, 22, 3196. [CrossRef] [PubMed]

110. Niu, D.; Wei, H.J.; Lin, L.; George, H.; Wang, T.; Lee, I.; Zhao, H.; Kan, Y.; Shrock, E.; Lesha, E.; et al. Inactivation of porcine endogenous retrovirus in pigs using CRISPR-Cas9. Science 2017, 357, 1303-1307. [CrossRef] 
111. Denner, J. Advances in organ transplant from pigs. Science 2017, 357, 1238-1239. [CrossRef]

112. Hryhorowicz, M.; Zeyland, J.; Stomski, R.; Lipinski, D. Genetically modified pigs as organ donors for Xenotransplantation. Mol. Biotechnol. 2017, 59, 435-444. [CrossRef]

113. Jinek, M.; Chylinski, K.; Fonfara, I.; Hauer, M.; Doudna, J.A.; Charpentier, E. A programmable dual-RNA-guided DNA endonuclease in adaptive bacterial immunity. Science 2012, 337, 816-821. [CrossRef]

114. Myers, E.W.; Sutton, G.G.; Delcher, A.L.; Dew, I.M.; Fasulo, D.P.; Flanigan, M.J.; Kravitz, S.A.; Mobarry, C.M.; Reinart, K.H.; Remington, K.A.; et al. A whole-genome assembly of Drosophila. Sciene 2000, 287, 2196-2204. [CrossRef]

115. Gratz, S.J.; Rubinstein, C.D.; Harrison, M.M.; Wildonger, J.; O'Connor-Giles, K.M. CRISPR-Cas9 genome editing in Drosophila. Curr. Protoc. Mol. Biol. 2015, 111, 1-20. [CrossRef] [PubMed]

116. Hammond, A.; Galizi, R.; Kyrou, K.; Simoni, A.; Siniscalchi, C.; Katsanos, D.; Gribble, M.; Baker, D.; Marois, E.; Russell, S. A CRISPR-Cas9 gene drive system targeting female reproduction in the malaria mosquito vector Anopheles gambiae. Nat. Biotechnol. 2016, 34, 78-83. [CrossRef] [PubMed]

117. Gratz, S.J.; Cummings, A.M.; Nguyen, J.N.; Hamm, D.C.; Donohue, L.K.; Harrison, M.M.; Wildonger, J.; O'Connor-Giles, K.M. Genome engineering of Drosophila with the CRISPR RNA-guided Cas9 nuclease. Genetics 2013, 194, 1029-1035. [CrossRef] [PubMed]

118. Bassett, A.R.; Tibbit, C.; Ponting, C.P.; Liu, J.L. Highly efficient targeted mutagenesis of Drosophila with the CRISPR/Cas9 system. Cell Rep. 2013, 4, 220-228. [CrossRef] [PubMed]

119. Yu, Z.; Chen, H.; Liu, J.; Zhang, H.; Yan, Y.; Zhu, N.; Guo, Y.; Yang, B.; Chang, Y.; Dai, F.; et al. Various applications of TALEN- and CRISPR/Cas9-mediated homologous recombination to modify the Drosophila genome. Biol. Open 2014, 3, 271-280. [CrossRef] [PubMed]

120. Gratz, S.J.; Ukken, F.P.; Rubinstein, C.D.; Thiede, G.; Donohue, L.K.; Cummings, A.M.; O'Connor-Giles, K.M. Highly specific and efficient CRISPR/Cas9-catalyzed homology-directed repair in Drosophila. Genetics 2014, 196, 961-971. [CrossRef] [PubMed]

121. Wang, H.; Yang, H.; Shivalila, C.S.; Dawlaty, M.M.; Cheng, A.W.; Zhang, F.; Jaenisch, R. One-step generation of mice carrying mutations in multiple genes by CRISPR/Cas-mediated genome engineering. Cell 2013, 153, 910-918. [CrossRef]

122. Liu, Y.; Ma, S.; Wang, X.; Chang, J.; Gao, J.; Shi, R.; Zhang, J.; Lu, W.; Liu, Y.; Zhao, P.; et al. Highly efficient multiplex targeted mutagenesis and genomic structure variation in Bombyx mori cells using CRISPR/Cas9. Insect Biochem. Mol Biol. 2014, 49, 35-42. [CrossRef]

123. Dong, S.; Lin, J.; Held, N.L.; Clem, R.J.; Passarelli, A.L.; Franz, A.W. Heritable CRISPR/Cas9-mediated genome editing in the yellow fever mosquito, Aedes aegypti. PLoS ONE 2015, 10, e0122353. [CrossRef]

124. Nakanishi, T.; Kato, Y.; Matsuura, T.; Watanabe, H. CRISPR/Cas-mediated targeted mutagenesis in Daphnia magna. PLoS ONE 2014, 9, e98363. [CrossRef] 